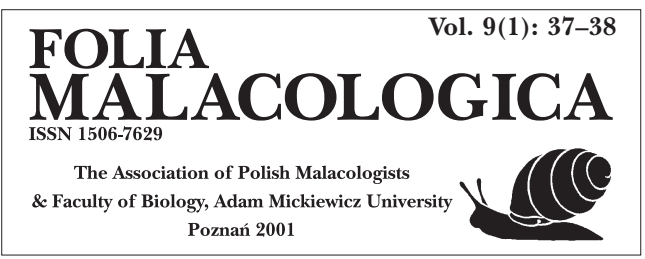

\title{
TAXONOMIC POSITION OF KASPERIA GODWIN-AUSTEN, 1914 (GASTROPODA: PULMONATA: LIMACIDAE)
}

\author{
ANDRZEJ WIKTOR \\ Museum of Natural History, Wrocław University, Sienkiewicza 21, 50-335 Wrocław, Poland, \\ (e-mail: awiktor@biol.uni.wroc.pl)
}

ABSTRACT: Examination of the type material of Limax (Kasperia) mayae Godwin-Austen, 1914 revealed that the subgeneric name Taulimax Wiktor et Likharev, 1980 is a junior synonym of Kasperia Godwin-Austen, 1914; the specific name mayae Godwin-Austen, 1914 is a synonym of turkestanus Simroth, 1898.

KeY WORDS: Gastropoda, Pulmonata, Limacidae, Kasperia, Turcomilax, Kashmir

GODWIN-AUSTEN (1914) described the subgenus Kasperia, simultaneously providing a description of a new species, Limax (Kasperia) mayae, which consequently became the type species (monotypy). The type specimens ( 5 syntypes) come from Tajwas (or Tajwaz; it was impossible to locate the name on the map), Sonamurg and Kashmir, and were collected in 1910 on old tree trunks by Miss M. PocKLINGTON. All those specimens, some damaged or incomplete, are deposited at The Natural History Museum in London. At present I designate the lectotype - the specimen whose genitalia are depicted in GODWIN-AUSTEN's paper (1914: Pl. CXL, Fig. 9). To my knowledge, this slug has not been collected in Kashmir any more, nor the taxonomic position of the subgenus revised since then.

Like the author of the name himself, i.e. GODWINAUSTEN (1914), HESSE (1926), LIKHAREV \& WIKTOR (1980) and recently WIKTOR et al. (1999) did not associate the name Kasperia with any known slug. The knowledge of the slug fauna of Kashmir is very scanty, and the name, both of the subgenus and species, i.e. Limax (Kasperia) mayae Godwin-Austen, 1914, had not appeared in the literature and must have been omitted.

Having examined the syntypes of Limax (Kasperia) mayae, I came to a conclusion that they are conspecific with the slug known as Turcomilax turkestanus (Simroth, 1898); thus, the name mayae is a junior synonym of turkestanus (Fig. 1).

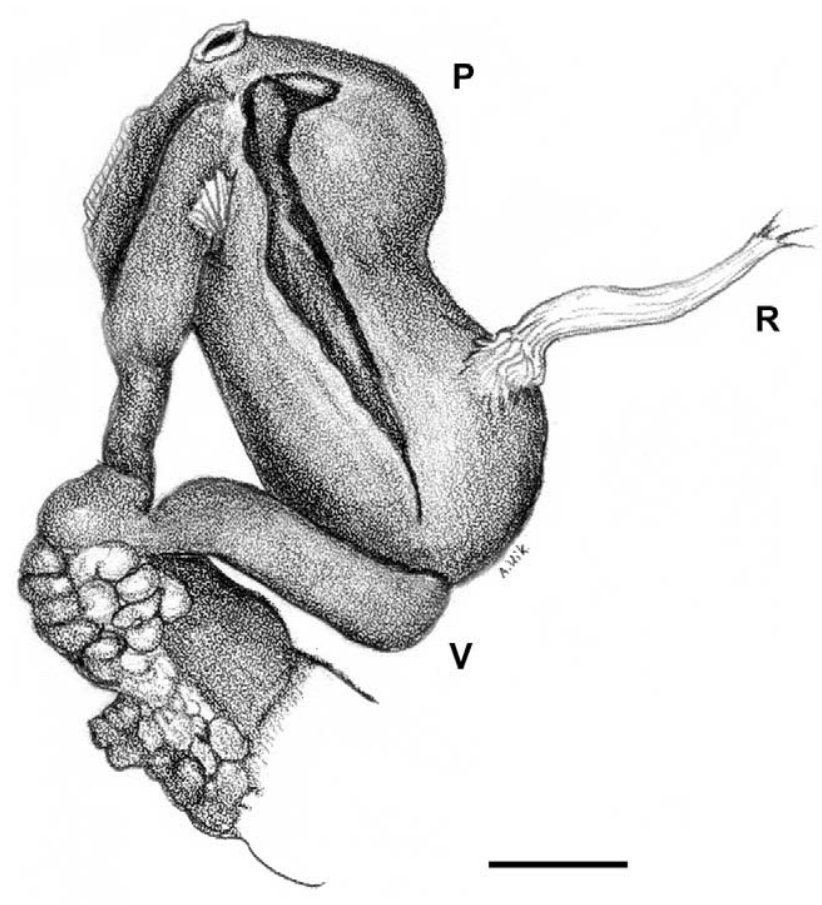

Fig. 1. Limax (Kasperia) mayae Godwin-Austen, 1914 - copulatory organs of the lectotype with the characteristically shaped penis and the lateral insertion of retractor penis typical of Turcomilax turkestanus (Simroth, 1898) (orig.). $\mathrm{O}$ - oviduct, $\mathrm{P}$ - penis, $\mathrm{R}$ - penial retractor muscle, $\mathrm{V}$ - vas deferens (scale bar $1 \mathrm{~mm}$ ) 
Within the genus Turcomilax, LIKHAREV \& WIKTOR (1980) described a new subgenus, giving it the name Taulimax, and Limax turkestanus Simroth, 1898 was designated as its type species. In view of this, the subgeneric name Taulimax Likharev et Wiktor, 1980 should be acknowledged as a junior synonym of Kasperia Godwin-Austen, 1914.

Since the genus Turcomilax is still poorly known and, additionally, it occurs in regions which will certainly be the subject of further zoological exploration, I think it is useful to rearrange the nomenclature of this group as attempted below.

\section{Family: Limacidae Rafinesque, 1815}

\section{Subfamily: Limacinae Rafinesque, 1815}

\section{Genus: Turcomilax Simroth, 1901}

(SIMROTH 1901: 176)

Type species: Gigantomilax (Turcomilax) nanus Simroth, 1901, by monotypy.

Subgenus: Turcomilax s. str.

Type species: Gigantomilax (Turcomilax) nanus Simroth, 1901, by monotypy.

Turcomilax (Turcomilax) nanus (Simroth, 1901) (SIMROTH 1901: 177, Pl. 19, Figs 15-20, as Gigantomilax (Turcomilax)).

Synonyms:

Gigantomilax (Turcomilax) abramovi Simroth, 1910 (SIMROTH 1910: 529, Pl. VII, Fig. 26 pars). Gigantomilax (Turcomilax) pischpekensis Simroth, 1910 (SIMROTH 1910: 530, Pl. VII, Figs 27-28).

Turcomilax (Turcomilax) ferganus (Simroth, 1910) (SimROTH 1910: 528, Pl. VII, Figs 22-25, as Gigantomilax (Turcomilax)).

\section{REFERENCES}

Altena van Regteren C. O. 1954. Notes sur les limaces. 2. Description d'une espèce nouvelle de Gigantomilax provenant des environs de Kouldja (China). Beaufortia 4: 47-50.

Godwin-Austen H. H. 1914. Land and freshwater Mollusca of India including South Arabia, Nepal, Burmah, Pegu, Tenasserim, Malay Peninsula, Ceylon, and other islands of the Indian Ocean. Vol. II. Part XII. London.

HESSE P. 1926. Die Nacktschnecken der palaearktischen Region. Abh. Arch. Moll. II(1): 1-152, T. 1-2.

LIKHAREV I. M., WiKTOR A. 1980. The fauna of slugs of the USSR and adjacent countries (Gastropoda terrestria nuda). Fauna SSSR. Molyuski III (5). Nauka, Leningrad (in Russian).

MICHAELIS E. 1892. Opisane novykh i maloizvestnykh mollyuskov yuzhnogo Altaya i severnoy Dzhungarii. Zap. Akad. Nauk St. Petersburg 69: 31-36.

\section{Subgenus: Michaelisia Likharev et Wiktor, 1980} (LIKHAREV \& WIKTOR 1980: 252)

Type species: Limax (Lehmannia) natalianus Michaelis, 1892, by original designation.

Turcomilax (Michaelisia) natalianus (Michaelis, 1892) (MiCHAELIS 1892: 31, Fig. 3).

Synonyms:

Limax (Lehmannia) stummeri Simroth, 1910 (SIMROTH 1910: 510, Pl. VI, Figs 11-12).

Gigantomilax (Turcomilax) iliensis Altena, 1954 (ALTENA 1954: 47, Figs 1-3).

\section{Subgenus: Kasperia Godwin-Austen, 1914}

(GODWIN-AUSTEN 1914: 312)

Type species: Limax (Kasperia) mayae Godwin-Austen, 1914 [= turkestanus Simroth, 1898].

Taulimax Likharev et Wiktor, 1980, syn. n.

(LIKHAREV \& WIKTOR 1980: 254)

Type species: Limax turkestanus Simroth, 1898, by monotypy.

Turcomilax (Kasperia) turkestanus (Simroth, 1898) (SIMROTH 1898: 54, as Limax).

Synonym: Limax (Kasperia) mayae Godwin-Austen, 1914 (GODWIN-AUSTEN 1914: 312, PL. CXI, Figs 1-12).

Turcomilax (Kasperia) tzvietkovi Likharev et Wiktor, 1980 (LIKHAREV \& WIKTOR 1980: 258, Figs 309-310).

Turcomilax (Kasperia) oli Wiktor, Naggs et Gupta, 1999 (WIKTOR et al. 1999: 225, Figs 1-6).

\section{ACKNOWLEDGEMENTS}

I express my gratitude to Mr. FRED NAGGS from The Natural History Museum in London for the loan of the types and the assistance in obtaining the relevant literature.
Simroth H. 1898. Ueber die Gattung Limax in Russland. Ann. Mus. St. Pétersburg 3: 124-135.

SimRoth H. 1901. Die Nacktschnecken des Russischen Reiches. St. Pétersburg.

SimRoth H. 1910. Kaukasische und asiatische Limaciden und Raublungenschnecken. Ezheg. Zool. Mus. imp. Akad. Nauk. St.-Pétersburg 15: 499-560.

WikTOR A., NAGGS F., GUPTA P. K. 1999. Turcomilax (Taulimax) olisp. n. of the Kumaun Himalaya, India (Gastropoda: Pulmonata: Limacidae). Malak. Abh. 19: 225-231.

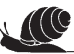

received: December 1st, 2000 accepted: January 15th, 2001 